\section{Ordforklaringer}

EBBA-studien: Energy Balance and Breast cancer Aspects. I denne studien deltok 204 kvinner i alderen 25-35 år. Østrogennivået i spyttet ble målt daglig gjennom menstruasjonssyklusen. Det ble også samlet informasjon om fødselsvekt, alder ved første menstruasjon, fysisk aktivitet og metabolsk profil.

Metabolsk profil: Kroppssammensetning, blodtrykk, blodsukker og fettstoffer i blodet.

\title{
Høyt østrogennivå gir risiko for brystkreft
}

\author{
Overvektige kvinner som er lite aktive fysisk, som hadde lav fødselsvekt \\ og fikk første menstruasjon i ung alder, har ofte høye østrogennivåer.
} Dette gir økt risiko for brystkreft.

Brystkreft er den hyppigste kreftformen hos kvinner. I Norge er brystkreft også vanligste dødsårsak hos kvinner i alderen 35-55 år. Antall nye brystkrefttilfeller øker parallelt med økende forekomst av overvekt og lite fysisk aktivitet i befolkningen. I avhandlingen Metabolic profile, physical activity, estradiol and breast cancer har Aina Emaus undersøkt faktorer som påvirker brystkreftrisiko og overlevelse.

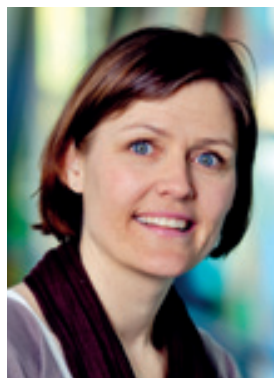

Aina Emaus. Foto nyebilder.no

\section{- Resultatene} viser at kvinner som hadde lav fødselsvekt, som får første menstruasjon i ung alder og er overvektige senere i livet, ofte får høye daglige østrogennivåer. Dette kan påvirke risikoen for å utvikle brystkreft. Vi ser også at lite fysisk aktivitet sammen med en ugunstig metabolsk profil påvirker nivået av østrogen. Dette kan også gi økt risiko for brystkreft. I oppfølgingsstudien av brystkreftpasientene fant vi at overvekt og lite fysisk aktivitet både før og etter diagnosen påvirker overlevelsen, sier Emaus.

Resultatene er basert på data fra den norske EBBA-studien og helseundersøkelser med 40000 kvinner i Finnmark, Oppland og Sogn og Fjordane i perioden 1974-87. I de fylkesvise helseundersøkelsene ble metabolsk profil og fysisk aktivite målt. I perioden 1974-2005 fikk 1364 av kvinnene brystkreft, og disse er fulgt i åtte år i gjennomsnitt.

Emaus disputerte for ph.d.-graden ved Universitetet i Oslo 27.3. 2009.

\section{Anne Forus}

anneforu@online.no

Tidsskriftet
Vestibularisschwannom: Godartet svulst på balansenerven. Siden hørselstap er det vanligste symptomet, er sykdommen blitt kalt acusticusnevrinomer, eller hørselsnervesvulster. I Norge blir det diagnostisert 70-90 nye svulster hvert år. Den sjeldne sykdommen har vært en av de mest utfordrende innen nevrokirurgien det siste århundret.

Strålekniv (gamma knife): Et apparat som sender gammastråling inn i hjernen fra flere kanter slik at strålene møtes i det punktet som skal behandles. På den måten kan stråledosen i svulsten bli større enn ved vanlig strålebehandling, samtidig som vevet rundt ikke blir utsatt for høyere stråling enn forsvarlig, ifølge Haukeland universitetssykehus.

Se oversikt over doktoravhandlinger i seksjonen Oss imellom på side 1427
Tips oss gjerne om doktoravhandlinger på tidsskriftet@legeforeningen.no

\section{Balansenervesvulster bør ikke røres}

\section{Pasienter med små eller middels store balansenervesvulster har redusert livskvalitet både før og etter kirurgisk behandling. Disse pasientene bør derfor ikke behandles.}

Vestibularisschwannomer er godartede, langsomtvoksende svulster på en av balansenervene. Symptomene er hørselstap på det ene øret, øresus, svimmelhet og ustøhet. Store svulster fjernes i et kirurgisk inngrep, små svulster fjernes enten kirurgisk eller ved hjelp av strålekniv. Haukeland universitetssykehus er det eneste sykehus i Norge som har strålekniv, derfor henvises de fleste av disse pasientene dit. Nevrokirurg Erling Myrseth har vurdert livskvaliteten til pasienter med balansenervesvulster, både de som er blitt behandlet kirurgisk eller med strålekniv og de som ikke har fått behandling.

- Pasienter med vestibularisschwannomer har redusert livskvalitet, i hovedsak på grunn av svimmelhet. Men hos dem med små eller middels store svulster gir ikke behandlingen noen bedring i livskvaliteten. Mange mister hørselen på det berørte øret, og ikke alle blir kvitt øresus og svimmelhet. Siden vi vet at dette er godartede svulster som vokser langsomt og siden vi ikke kan gjøre pasientene bedre, har det ingen hensikt å behandle dem, sier Myrseth.

Han understreker at store svulster som presser på hjernestammen bør opereres. Når det er nødvendig med behandling, er stråleknivsbehandling like effektivt og mindre risikofylt enn operativ behandling.

- Pasienter som opereres har større risiko for ansiktslammelse og hørselstap, sier Myrseth.

Han disputerte 27.2. 2009 ved Universitetet i Bergen med avhandlingen Clinical studies of vestibular schwannomas.

\section{Eline Feiring}

eline.feiring@legeforeningen.no

Tidsskriftet 